\title{
RANCANG BANGUN SISTEM INFORMASI PENYEWAAN WEDDING ORGANIZER BERBASIS WEB DENGAN PHP DAN MYSQL PADA KIKI RIAS
}

\author{
SRI MULYATI \& MIFTAHUR HISYAM \\ Program Studi Informatika \\ Fakultas Teknik Universitas Muhammadiyah Tangerang \\ Jl. Perintis Kemerdekaan 1/33 Cikokol Kota Tangerang \\ Email : lilysrimulyati@gmail.com
}

\begin{abstract}
ABSTRAK
Kiki Rias Wedding Organizer merupakan suatu pelayanan jasa pernikahan yang ada dikota Tangerang yang menyediakan beberapa jenis jasa pernikahan dan paket pernikahan yang pemesanannya masih secara manual. Hal ini menyebabkan sering dijumpai masalah calon pengantin tidak dapat menemui pemilik karena sedang tidak berada di tempat sehingga calon pengantin harus datang langsung ke Kiki Rias Wedding Organizer untuk memesan atau sekedar mengetahui informasi layanan jasa yang disediakan pada wedding organizer tersebut, konfirmasi pembayarannya masih harus datang ketempat. Dengan Seluruh proses tersebut meyebabkan beberapa masalah dalam efisiensi waktu dan kesulitan dalam pemesanan paket pernikahan. Untuk mengatasi hal tersebut maka dibangun sebuah sistem informasi pemesanan online paket pernikahan. Sistem tersebut menggunakan metode waterfall. Sistem ini menggunakan pengujian blackbox untuk mengetahui apakah data yang dimasukkan sudah benar atau belum serta bagaimana hasil keluarannya apakah sesuai dengan harapan atau tidak
\end{abstract}

Kata Kunci: Sistem Informasi, Wedding Organizer, Aplikasi,Web.

\section{PENDAHULUAN}

Perkembangan teknologi dapat mempengaruhi banyak aspek, di antaranya perekonomian, politik, pemerintahan, dan banyak lainnya. Pengaruh ini membuat banyak perubahan gaya hidup dan cara pandang masyarakat yang terbiasa dan berada di lingkungan teknologi. Mereka ingin di mudahkan dalam segala hal, salah satunya dalam bisnis perdagangan, mereka tidak ingin membuang waktu dan tenaga dalam memilih barang yang akan mereka inginkan. Mereka tidak begitu banyak membuang waktu dan tenaga untuk mendapatkan barang yang ingin mereka beli. Hal ini membuat banyak bisnis perdagangan persewaan, menjual atau menyewakan barang mereka melalui internet, dunia perdagangan tidak lagi dibatasi dengan ruang dan waktu. Mobilitas manusia yang tinggi menuntut dunia perdagangan mampu menyediakan layanan jasa dan barang dengan instan sesuai dengan permintaan konsumen.
Untuk mengatasi masalah tersebut maka kini muncul transaksi yang menggunakan media Internet untuk menghubungkan antara penyedia jasa dan konsumennya.

Kiki Rias Wedding Organizer merupakan suatu pelayanan jasa pernikahan yang ada di Kota Tangerang yang menyediakan beberapa jenis jasa pernikahan dan paket pernikahan yang pemesanannya masih secara manual. Hal ini menyebabkan sering dijumpai masalah calon pengantin tidak dapat menemui pemilik karena sedang tidak berada di tempat sehingga calon pengantin harus datang langsung ke Kiki Rias Wedding Organizer untuk memesan atau sekedar mengetahui informasi layanan jasa yang disediakan pada wedding organizer tersebut, konfirmasi pembayarannya masih harus datang ketempat. Dengan Seluruh proses tersebut meyebabkan beberapa masalah dalam efisiensi waktu dan kesulitan dalam pemesanan paket pernikahan. Mulai dengan berkembangnya teknologi 
sekarang ini wedding organizer sudah mulai berpindah dari proses manual ke dalam proses online yaitu dengan pembuatan wedding organizer yang berbasis web. Wedding Organizer adalah usaha yang bergerak di bidang jasa khususnya pada acara pernikahan, wedding organizer mempunyai banyak pilihan model acara pernikahan yang disesuaikan berdasarkan jumlah undangan, keuangan, catering, gedung, serta dekorasi pelaminan pengantin. Berdasarkan latar belakang diatas, maka peneliti mengambil judul "Rancang Bangun Sistem Informasi Penyewaan Wedding Organizer Berbasis Web Dengan Php dan Mysql Pada Kiki Rias.".

\section{LANDASAN TEORI}

\section{a. Pengertian Rancang Bangun}

Menurut Pressman (2010) Perancangan merupakan salah satu hal yang penting dalam membuat program. Adapun tujuan dari perancangan ialah untuk memberi gambaran yang jelas lengkap kepada pemrogram dan ahli teknik yang terlibat. Perancangan harus berguna dan mudah dipahami sehingga mudah digunakan.

Menurut Pressman (2010) pengertian pembangunan atau bangun sistem adalah kegiatan menciptakan sistem baru maupun mengganti atau memperbaiki sistem yang telah ada secara keseluruhan.

Jadi dapat disimpulkan bahwa Rancang Bangun adalah penggambaran, perencanaan, dan pembuatan sketsa atau pengaturan dari beberapa elemen yang terpisah kedalam suatu kesatuan yang utuh dan berfungsi. Dengan demikian pengertian rancang bangun merupakan kegiatan menerjemahkan hasil analisa ke dalam bentuk paket perangkat lunak kemudian menciptakan sistem tersebut atau memperbaiki sistem yang sudah ada.

\section{b. Pengertian Sistem Informasi}

Menurut Mulyanto (2009), "Sistem informasi adalah suatu komponen yang terdiri dari manusia, teknologi informasi, dan prosedur kerja yang memproses, menyimpan, menganalisis, dan menyebarkan informasi untuk mencapai suatu tujuan".

Menurut Jogiyanto HM (2009), "Sistem informasi merupakan suatu sistem yang tujuannya menghasilkan informasi."

Dari pendapat yang dikemukakan di atas dapat disimpulkan bahwa informasi adalah gabungan dari orang, hardware, software, ja- ringan komunikasi, sumber daya data, dan kebijakan dan prosedur yang menyimpan, mengumpulkan (mendapatkan kembali), memproses, dan mendistribusikan informasi untuk mendukung pengambilan dan pengontrolan keputusan dalam suatu organisasi.

\section{c. Pengertian Wedding Organizer}

Wedding Organizer adalah suatu jasa khusus yang secara pribadi membantu calon pengantin dan keluarga dalam perancanaan dan pelaksanaan rangkaian acara pesta pernikahan sesuai dengan jadwal yang telah ditetapkan. Wedding Organizer membantu memberikan informasi mengenai berbagai macam yang berhubungan dengan acara pernikahan diantaranya catering service, tata rias dan busana, florist dan dekorasi, gedung, photography, dan video shooting, mc dan hiburan serta undangan dan souvenir yang dibutuhkan dalam pernikahan. Adapun Ruang lingkup pekerjaan Wedding Organizer adalah sebagai berikut:

1. Memberikan informasi kepada calon pengantin mengenai hal-hal yang harus diperhatikan dalam perencanaan dan pelaksanaan upacara pernikahan.

2. Membantu perencanaan mengenai tema, alur/skenario acara, dekorasi pesta dan konsep pernikahan secara keseluruhan termasuk setting ruangan \& flow tamu di rumah maupun di tempat resepsi.

3. Menyusun budget, jadwal kerja, jadwal pembayaran dan mencari lokasi resepsi (bila belum ada).

4. Pengurusan persyaratan akad nikah \& perizinan lain-lain.

5. Fasilitasi, negosiasi dan koordinasi dengan pihak gedung/hotel dan supplier/vendor seperti: Catering, dekorasi, fotografer, rias pengantin, grup musik, dll.

6. Menghubungi setiap rekanan untuk follow up yang diperlukan.

7. Mengikuti rapat koordinasi dengan keluarga, juga memimpin rapat teknis dengan para rekanan.

8. Technical meeting di tempat resepsi \& menurunkan minimal 5 (lima) orang staff.

9. Mengkoordinasikan acara dan seluruh rekanan pada hari $\mathrm{H}$, memonitor proses dan detail acara serta membantu meng- 
ingatkan calon pengantin atau anggota keluarga yang berkepentingan mengenai hal-hal yang berkaitan dengan kelancaran penyelenggaraan acara.

10. Mengambil langkah-langkah pengamanan bila terjadi keadaan darurat (sebatas dengan kewenangan yang diberikan).

\section{d. Metode Waterfall}

Menurut Pressman (2010) model waterfall adalah model klasik yang bersifat sistematis, berurutan dalam membangun software. Berikut ini adalah gambaran dari waterfall model.

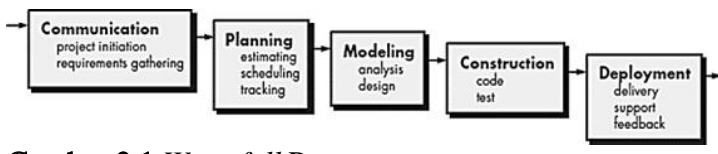

Gambar 2.1 Waterfall Pressman

\section{e. Unified Modeling Language (UML)}

Menurut Nugroho (2010), UML (Unified Modeling Language) adalah bahasa pemodelan untuk sistem atau perangkat lunak yang berparadigma (berorientasi objek). Pemodelan (modeling) sesungguhnya digunakan untuk penyederhanaan permasalahan-permasalahan yang kompleks sedemikian rupa sehingga lebih mudah dipelajari dan dipahami.

Menurut Joomla (2014), Unified Modeling Language (UML) merupakan standard modeling language yang terdiri dari kumpulan-kumpulan diagram, dikembangkan untuk membantu para pengembang sistem dan software agar bisa menyelesaikan tugastugas seperti: Spesifikasi, Visualisasi, Desain Arsitektur, Konstruksi, Simulasi dan testing serta Dokumentasi.

\section{METODE PENELITIAN \\ a. Teknik Pengumpulan Data \\ 1. Observasi}

Observasi dilakukan dengan melakukan pengamatan secara langsung Pada Kiki Rias, peneliti mengamati beberapa kegiatan sistem berjalan yang berhubungan dengan penelitian, seperti proses pemesanan wedding, pencatatan transaksi wedding, pencarian buku wedding. Observasi dilakukan di Kiki Rias. Observasi dilakukan untuk mengetahui dengan pasti kegiatan-kegiatan serta prosesproses yang berjalan pada Wedding Organizer Kiki Rias.

\section{Dokumentasi}

Dokumentasi dilakukan dengan cara pengambilan data melalui dokumen tertulis maupun elektronik dari lembaga/institusi. Dokumen diperlukan untuk mendukung kelengkapan data yang lain. Maka peneliti telah mencatat dan mengambil beberapa data dari Wedding Organizer Kiki Rias.

\section{Wawancara}

Wawancara dilakukan dengan cara meminta keterangan dari pihak-pihak yang berwenang untuk memberikan keterangan tentang data yang dibutuhkan agar data menjadi lebih lengkap dan jelas. Dalam melakukan wawancara pertanyaan ditunjukan kepada Kiki selaku pemilik wedding organizer. Kegiatan wawancara dilaksanakan pada tanggal 13 Juni 2018. Wawancara ini bertujuan untuk mempertegas dan mengetahui secara jelas proses sistem yang berjalan pada administrasi tabungan serta dapat memberikan data-data atau informasi yang dibutuhkan. Maka peneliti mengajukan beberapa pertanyaan yang sudah terlampir.

\section{ANALISIS DAN PEMBAHASAN \\ a. Analisis Sistem Yang Berjalan}

Wedding organizer memberikan informasi mengenai berbagai macam hal yang berhubungan dengan acara pernikahan, membantu merumuskan konsep pernikahan. Wedding organizer memfasilitasi, negosiasi dan koordinasi dengan pihak gedung, hotel, supplier, vendor seperti: catering, dekorasi, fotografer, perias, grup musik, dan lain-lain.

Salah satu wedding organizer yang ada di Tangerang yaitu Kiki Rias wedding organizer yang merupakan perusahaan beralamatkan di Jl KH Ahmad Dahlan RT 006/001 Petir Cipondoh, Kota Tangerang, Provinsi Banten.

Proses pemesanan paket di Kiki Rias wedding organizer masih tergolong manual, yaitu pelanggan mendatangi kantor Kiki Rias wedding organizer untuk melakukan pemesanan. untuk melakukan pemesanan paket pernikahan. Pencatatan yang dilakukan masih secara manual yaitu dengan menggunakan buku, sehingga memungkinkan data pelanggan yang memesan paket dapat hilang. 


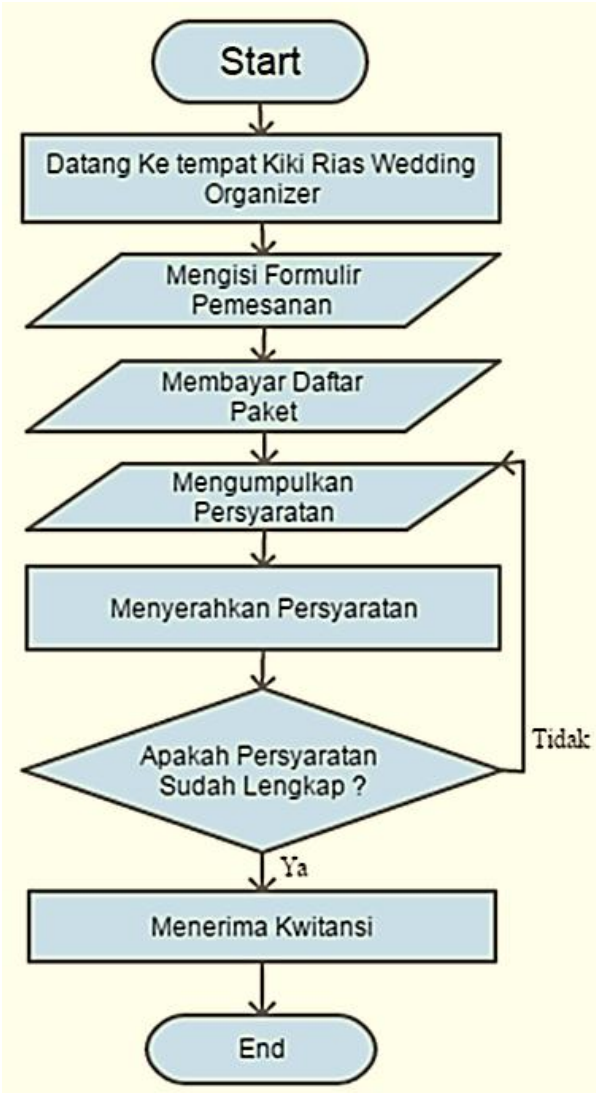

Gambar 4.1 Flowchart Penyewaan Wedding Organizer yang sedang berjalan.

\section{b. Gambaran Umum Sistem yang Diusul- kan}

Proses Pemesanan pelanggan membuka website kiki rias wedding organizer lalu melihat isi website tersebut, jika berminat pelanggan akan menghubungi kontak nomer yang tersedia di-website, lalu pelanggan akan memesan, merancang dan menstransfer biaya daftar paket pernikahan yang dipilih, lalu membayar sesusai prosedur pemesanan dengan cara mentransfer minimal 20\% harga daftar paket pernikahan yang akan dipilih, lalu setelah itu admin akan mengecek bukti transfer pelanggan jika benar akan segera dikelola data pemesanan pelanggan disistem.

\section{c. Perancangan Sistem Usulan}

Perancangan sistem usulan yang digunakan dalam pembuatan sistem aplikasi administrasi tabungan siswa berbasis java dan MySQL menggunakan UML (Unified Modeling Language).

1. Use Case Diagram Penyewaan Wedding Organizer

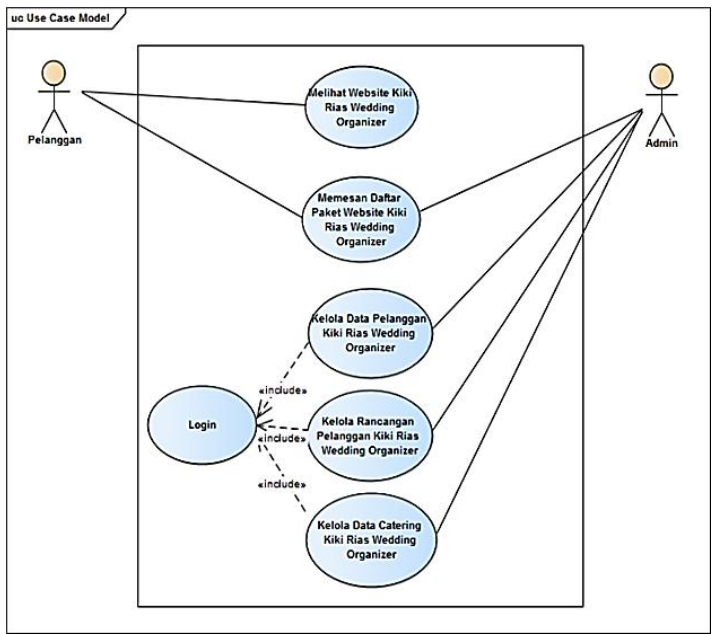

Gambar 4.2 Use Case Diagram Penyewaan Wedding Organizer.

2. Class Diagram

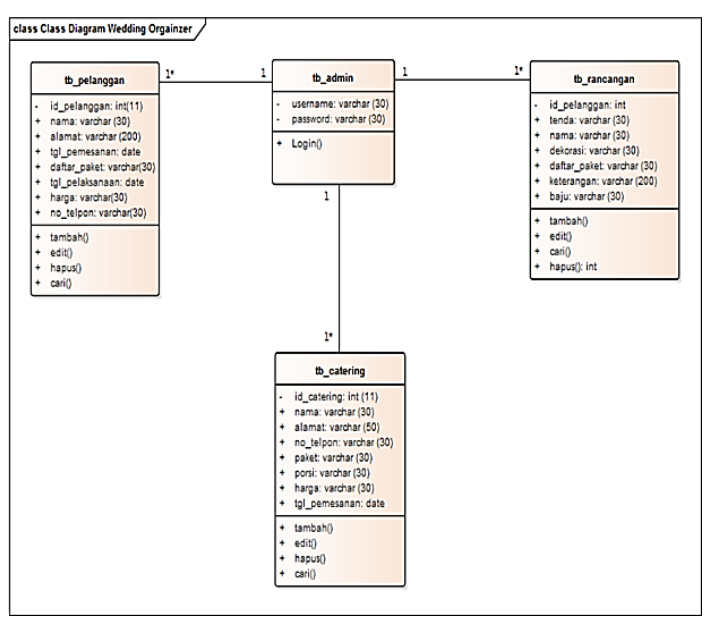

Gambar 4.3. Class Diagram Wedding Organizer.

\section{d. Rancangan Database}

Untuk rancangan database wedding organizer sebagai berikut:

1. Admin

File Name : tb_admin

Primary Key : username

Foreign Key : -

Tipe File : Data user

Tabel 4.1. Spesifikasi Database Tabel Admin.

\begin{tabular}{cccc}
\hline No & Field & Type & Value \\
\hline 1 & username & varchar & 20 \\
2 & password & varchar & 20 \\
\hline
\end{tabular}

2. Data Pelanggan

File Name : tb_pelanggan

Primary Key : id_pelanggan

Foreign Key : -

Tipe File : Data user

Tabel 4.2 Spesifikasi Database Tabel Data 
Pelanggan.

\begin{tabular}{llll}
\hline No & Field & Type & Value \\
\hline 1 & Id pelanggan & int & 11 \\
2 & nama & varchar & 30 \\
3 & alamat & varchar & 100 \\
4 & No_telpon & varchar & 15 \\
5 & Daftar_paket & varchar & 20 \\
6 & Tgl_pemesanan & date & \\
7 & Tgl_pelaksanaan & date & \\
8 & harga & varchar & 20 \\
\hline
\end{tabular}

3. Data Rancangan Pelanggan

File Name : tb_rancangan

Primary Key : id_pelanggan

Foreign Key : -

Tipe File : Data user

Tabel 4.3. Spesifikasi Database Tabel Rancangan Pelanggan.

\begin{tabular}{llll}
\hline No & Field & Type & Value \\
\hline 1 & Id_pelanggan & int & 11 \\
2 & nama & varchar & 30 \\
3 & Daftar_paket & varchar & 20 \\
4 & Warna_tenda & varchar & 30 \\
5 & dekorasi & varchar & 30 \\
6 & Baju_pengantin & varchar & 30 \\
7 & keterangan & varchar & 200 \\
\hline
\end{tabular}

4. Data Catering

File Name : tb_catering

Primary Key : id_pelanggan

Foreign Key :-

Tipe File : Data user

Tabel 4.4. Spesifikasi Database Tabel Data Catering

\begin{tabular}{llll}
\hline No & Field & Type & Value \\
\hline 1 & Id_pelanggan & int & 11 \\
2 & nama & varchar & 20 \\
3 & alamat & varchar & 100 \\
4 & No_telpon & varchar & 15 \\
5 & paket & varchar & 20 \\
6 & porsi & varchar & 20 \\
7 & harga & varchar & 20 \\
8 & Tgl_pemesanan & Date & \\
\hline
\end{tabular}

5. Jumlah Setoran Kelas
File Name
: tb_jumlah
Primary Key
: no_cetak
Foreign Key
: Data jumlah
Tipe File

setoran kelas
Setoran Kelas.

\begin{tabular}{cccc}
\hline No & Field & Type & Value \\
\hline 1 & no_cetak & int & 6 \\
2 & tanggal & date & \\
3 & kelas & enum & '1', '2', '3', '4', '5', '6' \\
4 & total_saldo & bigint & 20 \\
\hline & & &
\end{tabular}

e. Implementasi Sistem

1. Interface Halaman Login
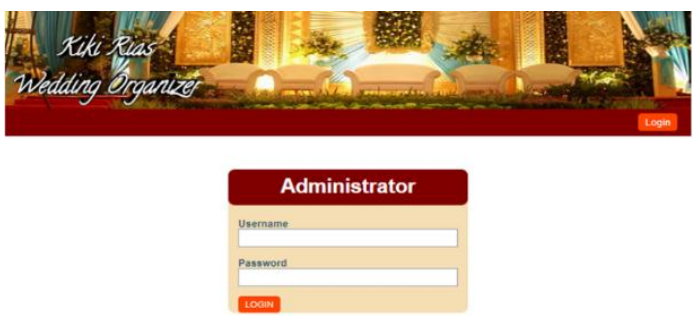

Gambar 4.4 Interface Halaman Login.

2. Interface Halaman Menu Utama

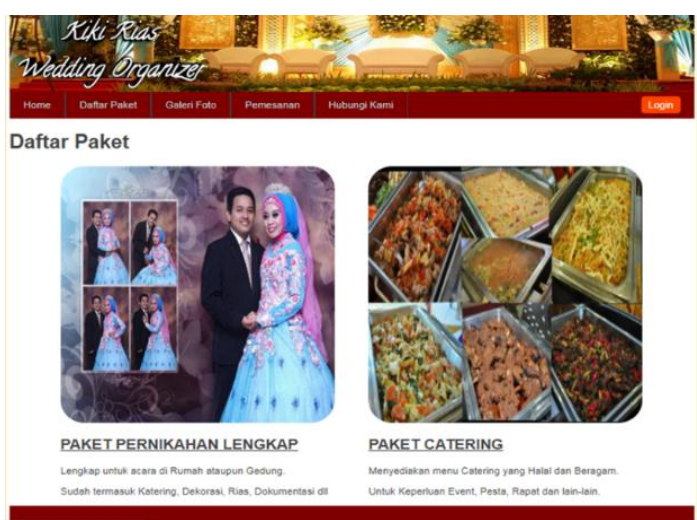

Gambar 4.5 Interface Halaman Menu Utama.

3. Interface Halaman Menu Data Pelanggan

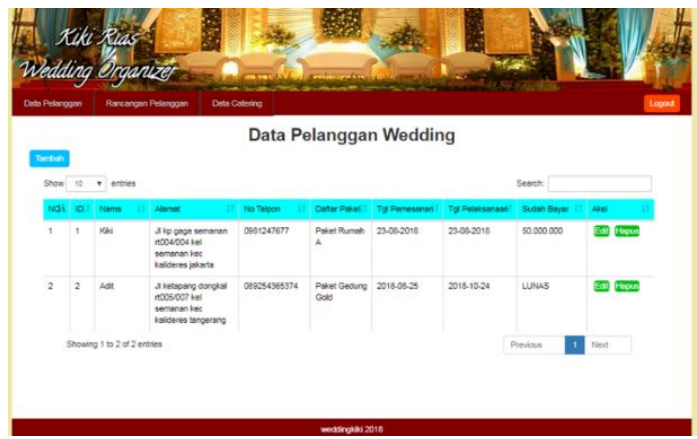

Gambar 4.6 Interface Halaman Data Pelanggan.

Tabel 4.5 Rancangan Database Tabel Jumlah

4. Interface Halaman Menu Data Rancangan Pelanggan 


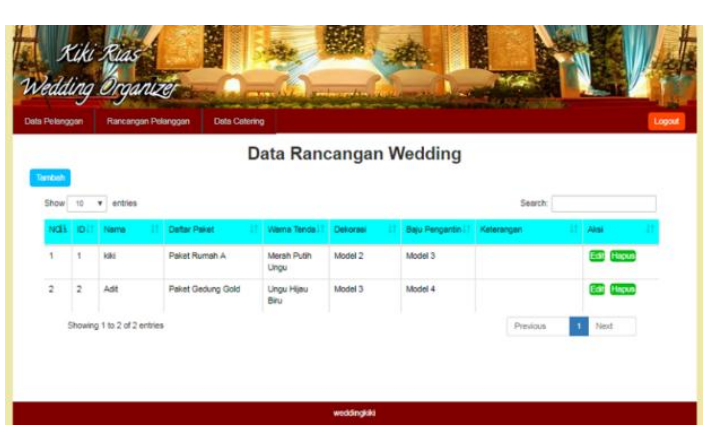

Gambar 4.7 Interface Halaman Data Rancangan Pelanggan.

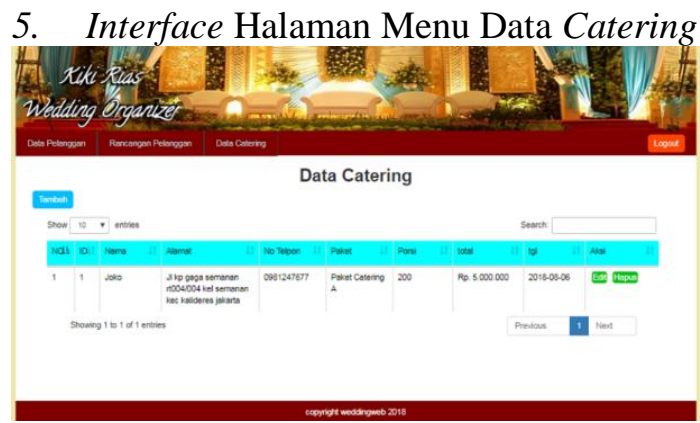

Gambar 4.8 Interface Halaman Data Catering.

6. Interface Halaman Menu Tambah

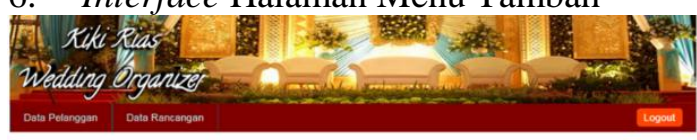

TAMBAH DATA

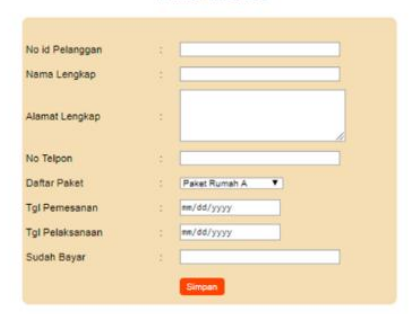

Gambar 4.9 Interface Halaman Tambah.

7. Interface Halaman Menu Edit

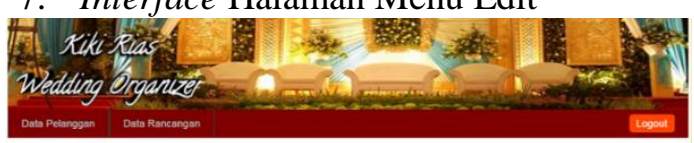

Edit Data

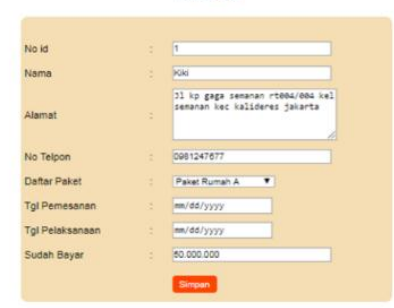

Gambar 4.9 Interface Halaman Edit.

\section{f. Pengujian Program}

Black box testing adalah pengujian yang dilakukan hanya mengamati hasil eksekusi melalui data uji dan memeriksa fungsional dari perangkat lunak. Tujuan black box testing adalah untuk membuat himpunan kondisi input yang akan melatih seluruh syarat-syarat fungsional suatu program. Berikut hasil test yang telah dilakukan:

Tabel 4.6 Pengujian Black Box Testing.

\begin{tabular}{|c|c|c|c|}
\hline No & Yang Diuji & $\begin{array}{l}\text { Hagil yarng Dimginkan } \\
\end{array}$ & Hasis \\
\hline 1 & Form Login & $\begin{array}{l}\text { Ketika memasukan data username dan } \\
\text { password dengan benar maka akan masuk } \\
\text { ke menu utama admin }\end{array}$ & Benar \\
\hline 2 & Form Data Pelanggant & $\begin{array}{l}\text { Ketika tombol diklik maka akan } \\
\text { menampilkan form menu data pelanggan }\end{array}$ & Benar \\
\hline 3 & Form Data Rancangan Pelanggan & $\begin{array}{l}\text { Ketika tombol diklik maka akan } \\
\text { menampilkan form menu data rancangan } \\
\text { pelangogan }\end{array}$ & Benar \\
\hline 4 & Form Data Catering & $\begin{array}{l}\text { Ketika tombol diklik maka akan } \\
\text { menampilkan form menu deta catering }\end{array}$ & Benar \\
\hline 5 & Tombol Tambah & $\begin{array}{l}\text { Ketika tombol tambah diklik maka akan } \\
\text { menginput data }\end{array}$ & Benar \\
\hline 6 & Tombol Edit & $\begin{array}{l}\text { Ketika tombol edit diklik maka akant } \\
\text { mengedit data }\end{array}$ & Benar \\
\hline 7 & Tombol Hapus & $\begin{array}{l}\text { Ketika tombol hapus diklik maka akan } \\
\text { menghapus data }\end{array}$ & Benar \\
\hline 8 & Tombol Cari & $\begin{array}{l}\text { Ketika tombol cari diklik maka akan } \\
\text { mencari data }\end{array}$ & Benar \\
\hline 9 & Form menu home & $\begin{array}{l}\text { Ketika tombol diklik maka akan } \\
\text { menampilkan form home }\end{array}$ & Benar \\
\hline 10 & Form menu daftar paket & $\begin{array}{l}\text { Ketika tombol diklik maka akan } \\
\text { menampilkan fora daftar paket }\end{array}$ & Benar \\
\hline 11 & Form menu galeri foto & $\begin{array}{l}\text { Ketika tombol diklik maka akan } \\
\text { menampilkan form galeri foto }\end{array}$ & Benar \\
\hline 12 & Form menu permesaman & $\begin{array}{l}\text { Ketika tombol diklik maka akan } \\
\text { menampilkan form pernesanan }\end{array}$ & Benar \\
\hline 13 & Form menu kontak kami & $\begin{array}{l}\text { Ketika tombol diklik makka akan } \\
\text { menampilkan form kontak kami }\end{array}$ & Benar \\
\hline
\end{tabular}

\section{KESIMPULAN}

Berdasarkan uraian pada bab-bab sebelumnya, maka pada penelitian ini penulis dapat menyimpulkan:

Sistem informasi pemesanan pada Kiki Rias wedding organizer yang saat ini masih berjalan secara manual, jadi diperlukannya sistem informasi mobile yaitu berbasis web

Sistem informasis berbasis web yang diterapkan pada Kiki Rias Wedding Organizer ini dapat lebih efektif dan efesien karna dapat membantu admin mengelola data pelanggan wedding organizer menggunakan komputer, dan juga membantu pemesanan pelanggan yang sesuai diinginkan.

\section{DAFTAR PUSTAKA}

Amin. (2012). Pemodelan Sistem Informasi Persediaan Barang Pada PT. Nutech Pundi Arta. Jakarta: Universitas Budi Luhur.

Davis, Gordon B. (2012). Kerangka Dasar Sistem Informasi Manajemen. Jakarta: Pustaka Binaman Pressindo.

Enger, Norman L. (2012). Analisis Sistem Informasi, Edisi II. Yogyakarta: Andi.

Jogiyanto. (2012). Sistem Informasi Teknologi. Yogyakarta: Andi Offset. 
McLeod, S. (2008). Sistem Informasi Manajemen. Jakarta: Salemba Empat.

Nugroho, Adi. (2010). Rekayasa Perangkat Lunak Menggunakan UML dan Java. Yogyakarta: Andi Offset.

Sutabri, Tata. 2012. Konsep Sistem Informasi. Yogyakarta: Andi Offset.
Pressman, Roger S. (2012). Rekayasa Perangkat Lunak - Buku Satu, Pendekatan Praktisi (Edisi 7). Yogyakarta: Andi.

Wikipedia. Pengertian Netbeans IDE 8.0.2. 1 Agustus 2018. https://id.wikipedia.org/wiki/NetBeans

Wikipedia. Pengertian Xampp. 1 Agustus 2018.

https://id.wikipedia.org/wiki/XAMPP 